\title{
Thermal assessment of heat mitigation strategies: the case of Portland State University, Oregon, USA
}

\author{
Mohammad Taleghani ${ }^{{ }^{*} 1,2}$, David Sailor ${ }^{2}$, Martin Tenpierik ${ }^{1}$, Andy van den Dobbelsteen ${ }^{1}$ \\ ${ }^{1}$ Faculty of Architecture and the Built Environment, Delft University of Technology, Delft, the \\ Netherlands. \\ ${ }^{2}$ Department of Mechanical and Materials Engineering, Portland State University, Portland, \\ OR, USA.
}

\begin{abstract}
Courtyard vegetation, high albedo surfaces, and courtyard ponds were investigated as potential heat mitigation strategies using field measurements and simulations in a university campus environment. The investigation was performed during a summer period in the temperate climate of Portland, Oregon, USA. In a comparison of seven locations on the campus, the maximum park cooling island effect recorded was $5.8^{\circ} \mathrm{C}$ between the heavily treed campus park and a nearby parking lot with asphalt pavement. Simulations of courtyards with vegetation and a water pond showed $1.6^{\circ} \mathrm{C}$ and $1.1^{\circ} \mathrm{C}$ air temperature reduction, respectively. Changing the albedo of the pavement in a bare courtyard from 0.37 (black) to 0.91 (white) led to $2.9^{\circ} \mathrm{C}$ increase of mean radiant temperature and $1.3^{\circ} \mathrm{C}$ decrease of air temperature.
\end{abstract}

\section{Keywords}

Heat mitigation, thermal comfort, courtyard, field measurement, ENVI-met simulation.

\section{Introduction}

The urban heat island (UHI) phenomenon results in higher air temperature in dense urban areas compared with their suburbs and rural surroundings. It varies among different cities based on morphology, location and climatic zone [1-3]. This phenomenon affects human health through thermal discomfort and air pollution [4-14] and the heating and cooling energy

\footnotetext{
${ }^{1}$ Corresponding author:

Mohammad Taleghani: m.taleghani@tudelft.nl ; mohamadtaleghani@gmail.com.

Co-authors' contacts:

David J. Sailor: sailor@pdx.edu

Martin Tenpierik: m.j.tenpierik@ tudelft.nl

Andy van den Dobbeslteen: a.a.j.f.vandendobbelsteen@tudelft.nl
} 
demands of buildings in cities [15-17]. Moreover, Hart and Sailor [18] explain that the intensity of $\mathrm{UHI}$ in a city depends on a) the geometry of the built environment (mainly buildings) $[19,20]$, b) the characteristics and the materials of the surfaces [21-23], and c) the anthropogenic activities [24].

The geometry effect relates to building densities, sky view factor (SVF) in urban spaces, height to width ratio of buildings (their shading effect), and canyon orientations with sun and prevailing winds. The surface characteristics factor is related to the relative availability of surface moisture and the thermal mass and reflectivity of various construction materials. Finally, waste emissions from energy use in cities can introduce a significant source of both heat and moisture.

Urban university campuses often have extensive areas of vegetation and green, and thus offer a unique opportunity to investigate possible mitigation strategies to cope with the negative impacts of the $\mathrm{UHI}[25,26]$. This paper considers the campus of Portland State University in Portland, Oregon, USA. To date, UHI has not been studied continuously during day and night in Portland. Portland has a temperate climate with warm dry summers and cool wet winters (Köppen-Geiger classification Csb). To fill this knowledge gap, this paper reports on field measurements and simulations of the campus in the downtown of Portland metropolitan.

\section{Literature review on heat mitigation strategies}

Vegetation has been studied in urban climates [27], mostly in regard to the urban heat island effect (first studied by Luke Howard in the early $19^{\text {th }}$ century [28]). In contrast to the urban heat island $(\mathrm{UHI})$, the park cool island $(\mathrm{PCI})$ can reduce the air temperature up to $3-4^{\circ} \mathrm{C}$ in summer [2, 3, 27, 29, 30]. Vegetation cools the environment through two mechanisms [31]:

1. With a higher albedo (typically $0.18-0.22$ ) compared to common pavements such as asphalt (typically $0.05-0.15$ ), vegetation reflects more solar radiation [32]; moreover, with a lower specific heat capacity, green areas accumulate less heat [29, 33].

2. By evapotranspiration, which is the sum of evaporation (from the earth's surface) and transpiration (from vegetation), the ambient air is cooled [1, 24, 34].

Several studies in various climates have addressed different heat mitigation strategies in urban spaces. Some of these investigations representing different climates are discussed 
here. A recent study using measurement and simulation was conducted by Srivanit and Hokao [26] in an institutional campus in the subtropical-humid climate of Saga, Japan. These researchers reported that the average daily maximum temperature would decrease by $2.7^{\circ} \mathrm{C}$ when the quantity of the trees was increased by $20 \%$ in the campus area. A key limitation of this study was the sole focus on air temperature, $\mathrm{T}_{\mathrm{a}}$; however, several other studies have shown the importance of mean radiant temperature, $T_{\text {mrt }}$, on outdoor thermal comfort [35-37]. As an example of a field measurement, in the subtropical-Mediterranean climate of Lisbon Oliveira, Andrade and Vaz [38] studied the thermal performance ( $T_{a}$ and $T_{m r t}$ ) of a small green space (0.24 ha). They found that the green area of interest was cooler than the surrounding areas, either in the sun or in the shade. Their measurement showed the highest difference was $6.9^{\circ} \mathrm{C}$ for $T_{a}$ and $39.2^{\circ} \mathrm{C}$ for $T_{m r t}$.

Moreover, SVF and its effect on the amount of radiation is another important factor affecting thermal comfort in urban areas [39, 40]. In the tropical climate of Taiwan, Lin, Matzarakis and Hwang [41] considered the outdoor thermal comfort index PET (Physiological Equivalent Temperature) for a field measurement at the National Formosa University campus. They indicated that a high SVF (barely shaded) causes discomfort in summer and in contrast, a low SVF (highly shaded) causes discomfort in winter.

Studies related to $\mathrm{PCI}$ and $\mathrm{UHI}$ are not limited to tropical and Mediterranean climates. Considering a colder climate, the influence of three urban parks on air temperature in a high latitude city (Göteborg, Sweden) was studied by Upmanis, Eliasson and Lindqvist [42] over one and half year period. The maximum temperature reduction occurred during the summer and was equal to $5.9^{\circ} \mathrm{C}$. Moreover, the extension of the cooling effect of the parks into the city (built up areas) was $1100 \mathrm{~m}$.

Furthermore, in the semi-arid climate of Ouagadougou (Burkina Faso), Lindén [43] reported that while the evening $\mathrm{UHI}$ effect reached only $1.9^{\circ} \mathrm{C}$ (warmer), the cool island effect in a dense and irrigated park was $5.0^{\circ} \mathrm{C}$ (cooler) compared to the dry rural reference. Regarding hot and arid areas, Spronken-Smith and Oke [44] showed that the type of vegetation also greatly influences the cooling effects, as irrigated parks in daytime stay significantly cooler than their surroundings, while areas with dry dead grass or bare soil can be hotter than their environments. They also showed that the $\mathrm{PCl}$ effect is different in various climates. They reported that parks in Vancouver, $\mathrm{BC}$, Canada, are typically $1-2^{\circ} \mathrm{C}$ cooler than their surroundings, while in Sacramento, CA, USA, irrigated green spaces can be $5-7^{\circ} \mathrm{C}$ cooler. 
Considering the temperate climate of Portland (Oregon, USA) as the case study of this research, George and Becker [45] in a spatial variability investigation of the Portland UHI found temperature differences across the Portland metropolitan area of up to $10^{\circ} \mathrm{C}$. Their temperature measurements were taken just prior to sunrise on a November morning. Later on Hart and Sailor [18] in a study on the influence of land use and surface characteristics on day time UHI of Portland, used vehicle temperature traverses to determine spatial differences in summertime air temperature (2 $\mathrm{m}$ height) in morning and evening. They showed that the downtown core was not the warmest part of the Portland metropolitan area. The most important urban characteristic separating warmer from cooler regions of the Portland metropolitan area was canopy cover and local shading effects in the urban canyons.

\section{Methodology}

In this research, different heat mitigation strategies at three spatial scales (covering three phases of the study) are considered. Phase 1 (scale 1) focused on 7 locations on the campus of Portland State University. On these locations, air temperature and relative humidity were measured (over the period of two months with 30 minutes of time step). Computer simulation was also used to analyse the thermal behaviour of the campus in presence of the existing vegetation, and in the case of two hypothetical variations-removal of vegetation, and addition of water ponds in the campus. Phase 2 (scale 2) focused on three courtyards on the campus which were either bare, green or with a water pond. This phase of the study explored the impacts of heat mitigation strategies in the courtyards as small microclimates. Phase 3 (scale 3 ) focused on the thermal behaviour of one of the courtyards studied in Phase 2, an educational building from the campus called Shattuck Hall. Shattuck Hall was selected because it has a terrace courtyard. In addition, restricted access to the courtyard made it easier for the researchers to make modifications to the albedo of the ground surface (Figure 1). All three of these phases of research were conducted in July and August 2013. 

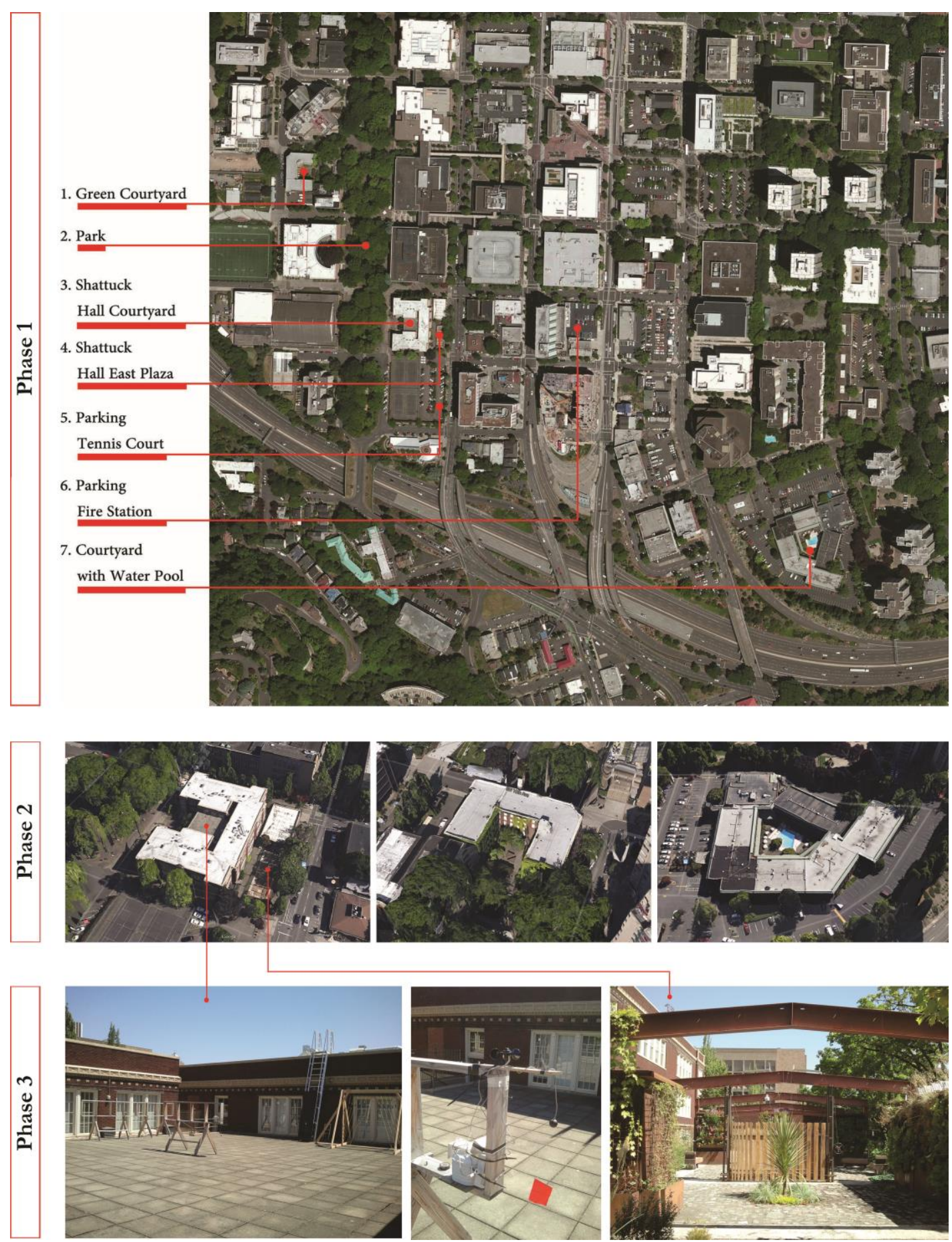

Figure 1: The research phases: Phase 1 - seven spots on the campus; Phase 2 - three courtyards with different characteristics (from left to right: bare, green and with water); Phase 3 - Shattuck Hall building.

\subsection{Field measurements}

Field measurements used HOBO U12-006 data loggers with three external sensors for air temperature, globe temperature and wind speed (Figures 1 and 2). A FLIR-i5 infrared 
camera was used for thermal photography. Finally, a spectrophotometer (Perkin Elmer Lambda 950- UV/Vis/NIR) was used to determine spectral reflectivity and albedo of surface materials used in this study.
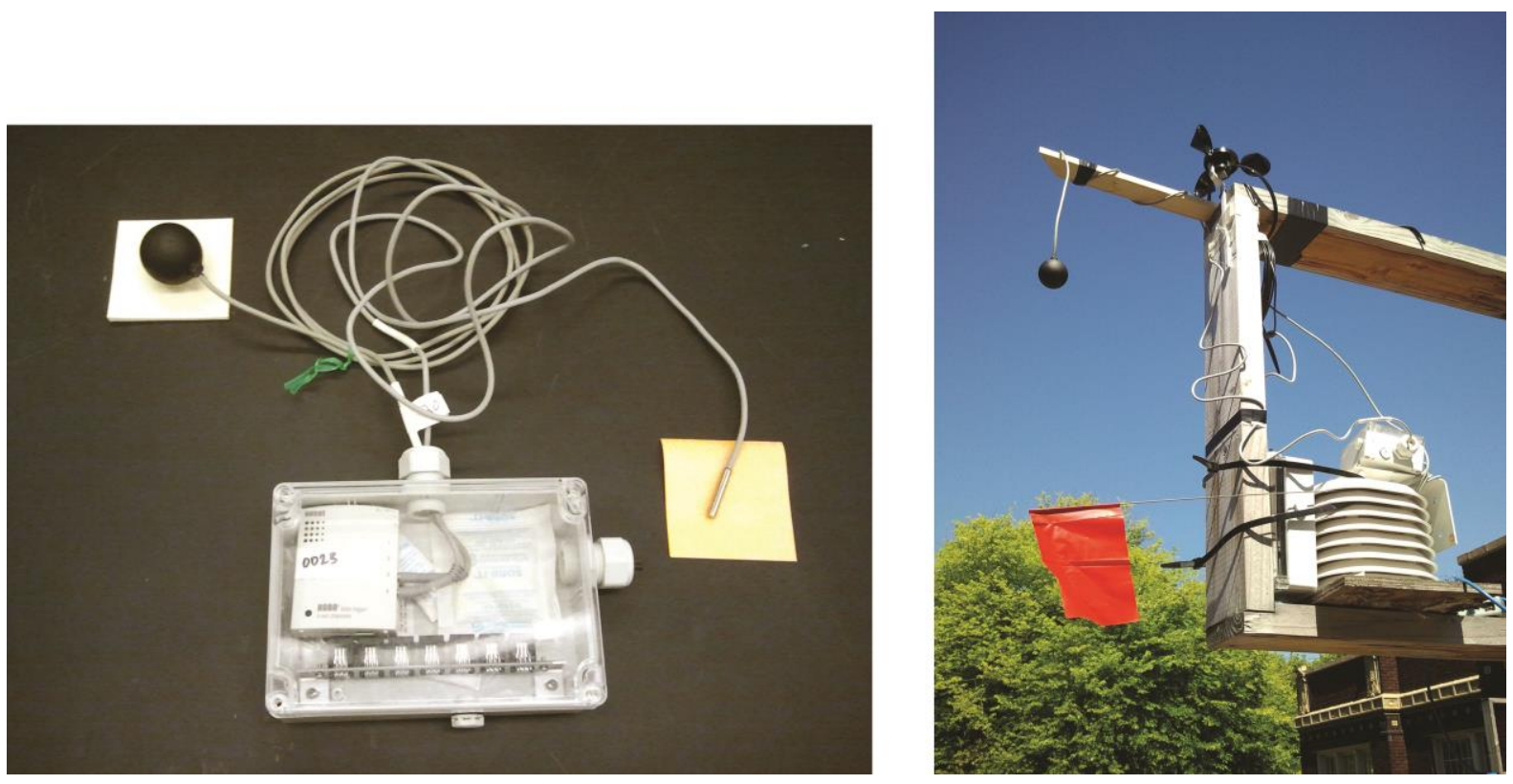

Figure 2: HOBO connected to air and globe temperature sensors (left) and in its final appearance in the field, connected to wind sensor (right).

\subsection{Simulations}

All simulations were conducted using the urban computational fluid dynamics software ENVImet 3.1 [46]. This program is a three-dimensional microclimate model designed to simulate the surface, plant and air interactions in an urban environment. ENVI-met is generally used with a typical spatial resolution of 0.5 to 10 meters in space and 10 second in time. It calculates the air temperature $\left({ }^{\circ} \mathrm{C}\right)$, water vapour pressure $(\mathrm{hPa})$, relative humidity $(\%)$, wind velocity $(\mathrm{m} / \mathrm{s})$ and mean radiant temperature $\left({ }^{\circ} \mathrm{C}\right)$ [47]. The spatial resolution used in the simulations is $2 \mathrm{~m}$ horizontally and vertically. This program is a prognostic model based on the fundamental laws of fluid dynamics and thermodynamics that can simulate exchange processes of heat and vapour at the ground surface and at walls, flows around and between buildings. This program has been extensively validated and widely used for studying the effect of climate change $[48,49]$ and the impact of natural elements on a microclimate $[47$, $50,51]$.

\subsection{Climate of Portland}


Portland $\left(45^{\circ} \mathrm{N}, 122^{\circ} \mathrm{W}\right)$ experiences a temperate oceanic climate typified by warm, dry summers and mild, damp winters [52]. Its climate is classified as a dry-summer subtropical or Mediterranean climate zone (Csb) based on the climatic classification of Köppen-Geiger [53]. The prevailing wind is North-West. The mean annual dry bulb temperature is $12.4^{\circ} \mathrm{C}$ (Figure 3 ).
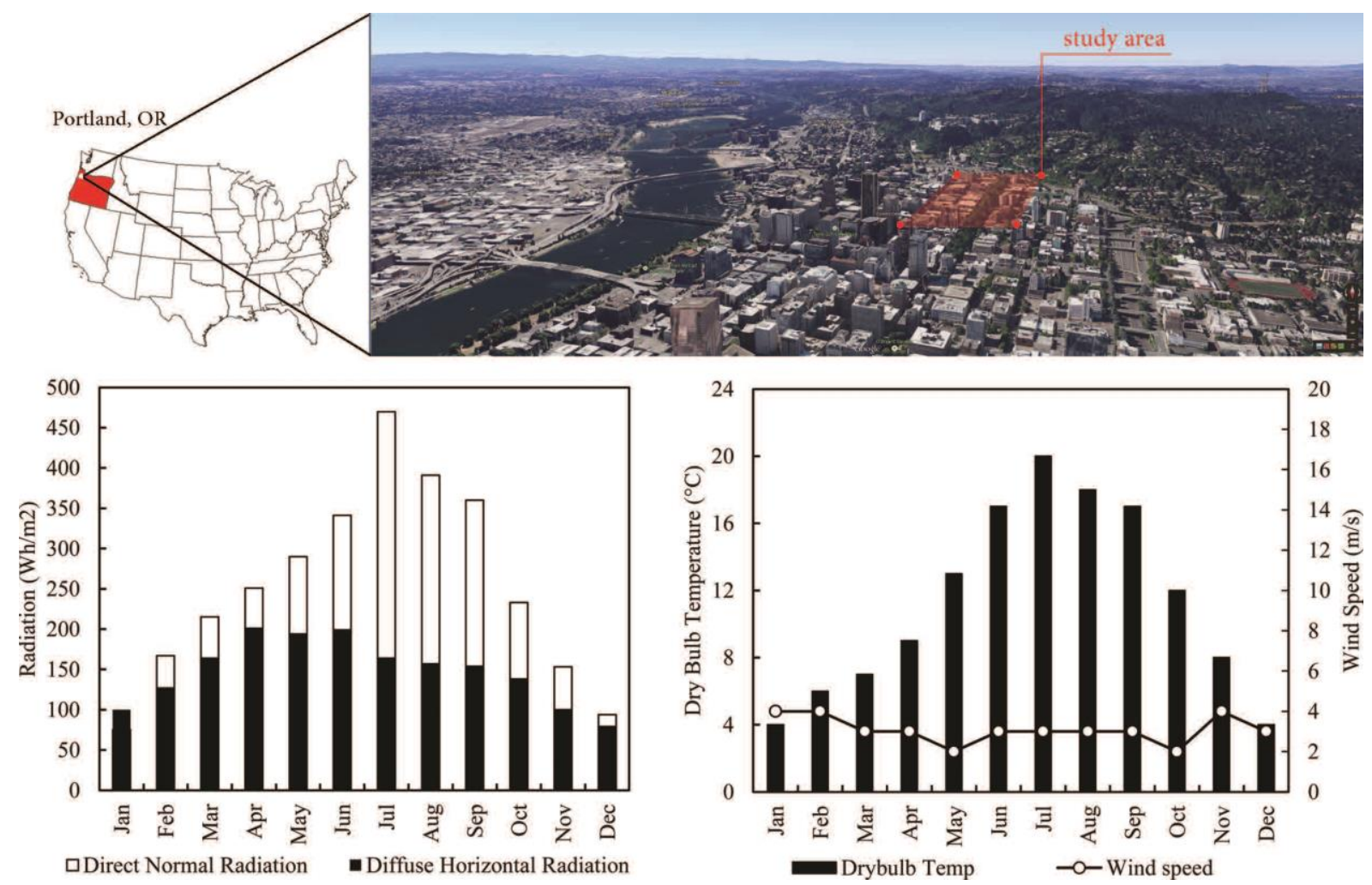

Figure 3: The position and climatic conditions of Portland, OR.

\section{Results and discussion}

\subsection{Scale 1: the campus microclimate}

In this phase of the study, seven locations on the campus with different microclimate characteristics were measured in July 2013. These microclimates range from very bare (Shattuck Hall courtyard) to very green (the campus park). The main aim was to understand how vegetation can affect the local thermal environment. These measurements with HOBO devices are described in Table 1 with maximum and minimum temperatures present on the seven locations. It was observed that the park had the coolest temperature; therefore, the maximum temperature differences between the park and the six other spots are calculated and demonstrated in Table 1. 


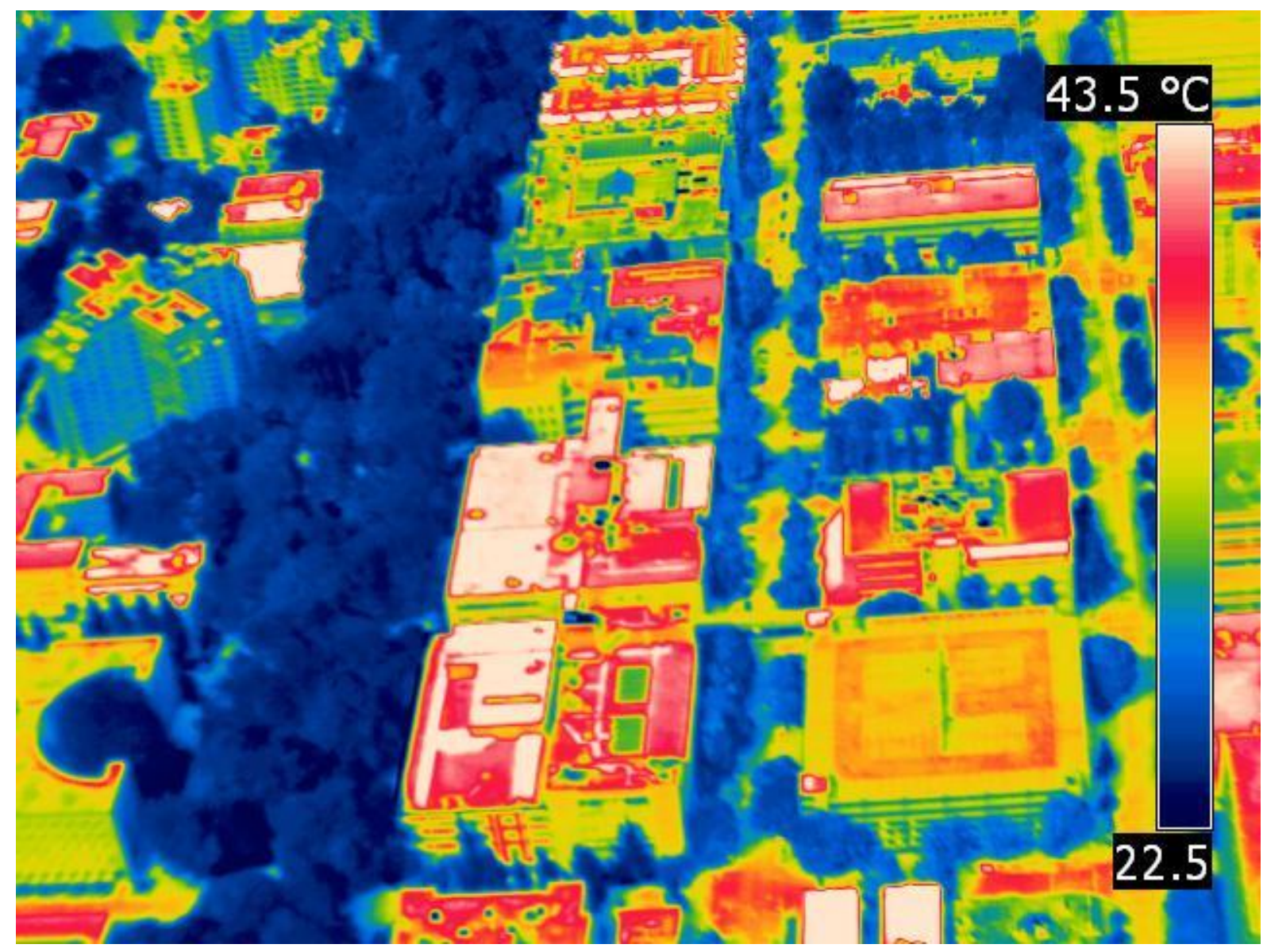

Figure 4: Thermography of the campus park and the surroundings from a prior study (August $\left.23^{\text {rd }}, 2011\right)$.

The maximum temperature in the Shattuck Hall courtyard reached to $32.1^{\circ} \mathrm{C}$ at $15: 30 \mathrm{PM}$. This location receives sun from the early morning, and has asphalt pavement. The minimum temperature here recorded was $12.2^{\circ} \mathrm{C}$ at $5: 30$ in the morning, which was $3.1^{\circ} \mathrm{C}$ cooler than the green courtyard, and $6.8^{\circ} \mathrm{C}$ cooler than the parking of the fire station at the same time. This courtyard is bare and there is no vegetation to obstruct night re-radiation (heat re-flux to the sky), resulting in more substantial nocturnal cooling that at any other location measured (Figure 5).

As an obstruction the vegetation made the microclimate of the park more moderate (with less temperature fluctuations) among the measured locations. The closest microclimate to the park is the green courtyard at the north-west of the campus. The two parking lots at the campus have similar thermal behaviour since they are both open to the sky (no vegetation) and their pavements are made of asphalt. The maximum temperature differences occurred with $5.8^{\circ} \mathrm{C}$ between the park and the parking of the fire station at 10:30 AM (July $27^{\text {th }}$ ). 
Comparing a parking lot and a park, thermal mass of the open space parking plays an important role. The parking lot is covered with asphalt with a high heat capacity. This heat releases with a delay during the night and it causes a similar temperature difference with park $\left(5.7^{\circ} \mathrm{C}\right.$ at 2:30 AM). In contrast, the vegetation in the park has absorbed less sun.

To understand the behaviour of the heat fluctuations in the campus, the continuously five days recorded data of the park, Shattuck hall courtyard, the green courtyard and the parking of fire station are illustrated in Figure 5.

Table 1: maximum, minimum and the differences of temperature of the measured spots.

\begin{tabular}{|l|l|l|l|l|}
\hline & $\begin{array}{l}\text { Max } \\
{\left[{ }^{\circ} \mathrm{C}\right]}\end{array}$ & $\begin{array}{l}\text { Min } \\
{\left[{ }^{\circ} \mathrm{C}\right]}\end{array}$ & $\begin{array}{l}\text { Max } \Delta \mathrm{T}\left[{ }^{\circ} \mathrm{C}\right] \\
\text { with park, Day }\end{array}$ & $\begin{array}{l}\text { Max } \Delta \mathrm{T}\left[{ }^{\circ} \mathrm{C}\right] \\
\text { with park, Night }\end{array}$ \\
\hline 1. Green courtyard & 28.7 & 14.4 & 2.3 & 2.4 \\
\hline 2. Park & 23.0 & 15.5 & - & - \\
\hline 3. Shattuck Hall courtyard & 32.1 & 12.2 & 2.8 & 0.2 \\
\hline 4. Shattuck Hall east plaza & 33.8 & 12.6 & 5.2 & 0.5 \\
\hline 5. Parking tennis court & 32.4 & 16.1 & 4.2 & 3.8 \\
\hline 6. Parking fire station & 32.1 & 16.8 & 5.8 & 5.7 \\
\hline 7. Courtyard with water pool & 27.9 & 15.9 & 4.3 & 3.2 \\
\hline
\end{tabular}

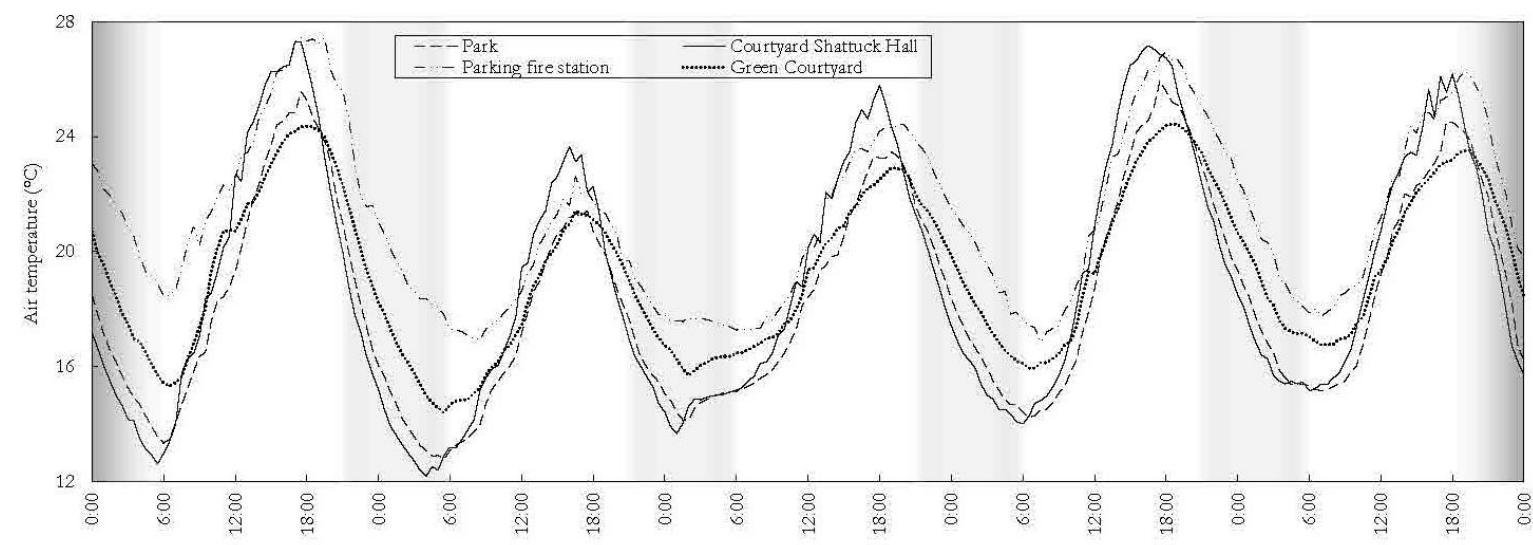

Figure 5: Temperature comparison between different locations on the campus.

The data presented here were related to the cooling effect of the campus park. The Portland Airport (PDX) weather station was selected as a reference for measuring UHI. This station is 
located approximately $17.5 \mathrm{~km}$ north-east from the downtown (and the campus), near a large body of water (the Columbia River) and in a suburban area. To evaluate the UHI, the hottest and coolest points on the campus (the campus park and the parking of the fire station, respectively) are compared with the airport in Table 2 . The UHI was evaluated during the day (sunrise to sunset) and night. The parking lot during the night had the maximum temperature difference with the airport $\left(7.3^{\circ} \mathrm{C}\right.$ warmer $)$. In contrast, the temperature difference between the park and the airport was larger during the day. The following explanation may apply. The airport located in the suburbs has larger temperature fluctuations during the day and night since it is open to the sky. The park on the other hand is covered with trees and has a more sheltered environment leading to smaller temperature fluctuations.

Table 2: Timing and magnitude of largest UHI (relative to the airport station) as measured at the park and fire station parking lot both at night and during the day.

\begin{tabular}{|l|c|c|}
\hline & $\mathrm{UHI}\left[{ }^{\circ} \mathrm{C}\right]$, day & $\mathrm{UHI}\left[{ }^{\circ} \mathrm{C}\right]$, night \\
\hline Park & $4.7(15: 30 \mathrm{PM})$ & $2.4(0: 00 \mathrm{AM})$ \\
\hline Parking fire station & $6.2(15: 30 \mathrm{PM})$ & $7.3(2: 00 \mathrm{AM})$ \\
\hline
\end{tabular}

To better understand the effect of the park, the campus area was simulated in ENVI-met using three scenarios: a) the actual situation in the campus, b) a bare campus with no vegetation, and c) a campus in which the park is replaced with water ponds. The results presented in Figure 6 illustrate the three scenarios at the hottest hour of the day (18:00 PM on July $20^{\text {th }}$ ). As it is seen in the first (actual) scenario, the park provides the coolest place on the campus. Moreover, since the prevailing wind is north-west, the park cooling effect seems to extend towards south-east. Consequently, the air temperature in the whole campus ranges between $24.1^{\circ} \mathrm{C}$ and $26.4^{\circ} \mathrm{C}$.

In the second scenario, the park is removed and it is visible that the air temperature in the whole area has increased. The air temperature here ranges from $25.8^{\circ} \mathrm{C}$ to $27.8^{\circ} \mathrm{C}$. Considering the tennis court and its parking which are covered with asphalt (located at the south middle), the differences between the scenarios are more visible. In the third scenario, the park is replaced by water ponds. The results show that the air temperature of different spots on the campus is between that of scenario 1 and $2\left(25.0^{\circ} \mathrm{C}-27.3^{\circ} \mathrm{C}\right)$. 
To have a daily comparison among the scenarios, Figure 7 shows the air temperature from a receptor at the Shattuck Hall courtyard. This figure shows that the differences of the air temperatures mostly occurred in the afternoon. At this moment of the day, the second scenario has absorbed much solar energy because it is not obstructed by vegetation and is made of low-albedo pavement. Moreover, in the first scenario and the third scenarios, the evapotranspiration and transpiration processes keep the campus cooler than in the second scenario. Finally, the maximum temperature difference in the courtyard of Shattuck Hall between the actual situation (first scenario) and the second and the third scenarios is $1.6^{\circ} \mathrm{C}$ and $1.1^{\circ} \mathrm{C}$, respectively. 

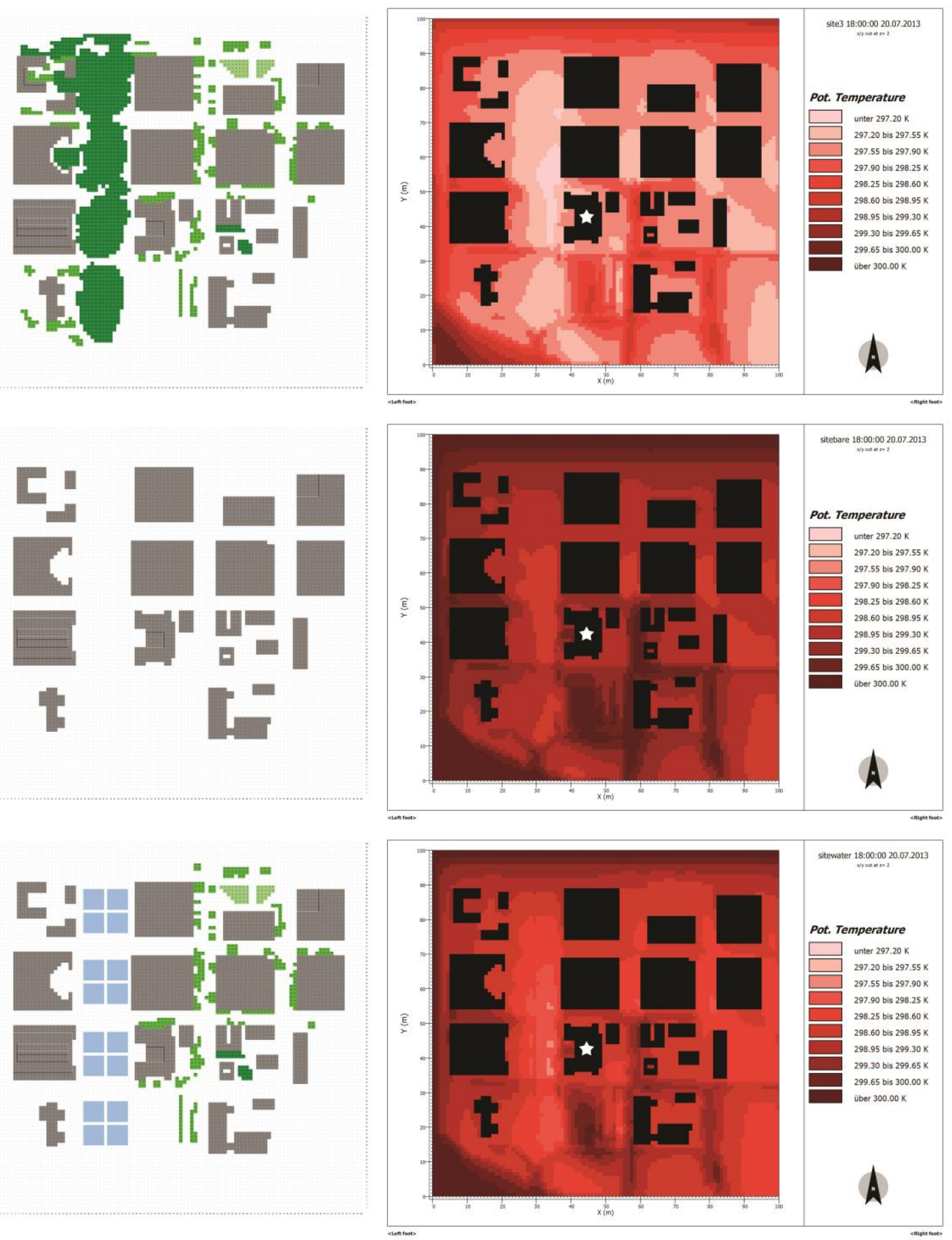

Figure 6: Left, first scenario, the actual situation. Middle, the second scenario, the campus with no vegetation. Right, the third scenario, the park is replaced by water pools. Shattuck Hall Building is highlighted with a white star at the centre. 


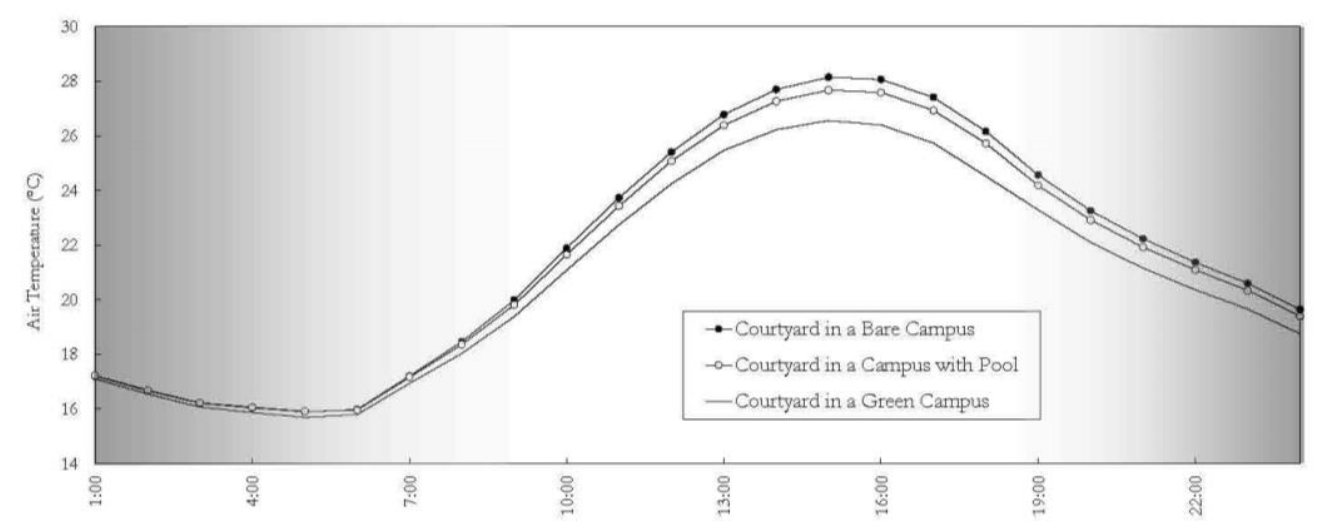

Figure 7: The air temperature of Shattuck Hall courtyard in the three campus scenarios.

\subsection{Scale 2: the three courtyards}

In this phase of the study, three courtyards in the campus were studied. These courtyards are numbered in Figure 1-a), as the first, third and seventh location. Although the materials and the configurations of the spots (buildings) are not identical, the main aim of this phase of the study was to see how the air temperature differs in these microclimates at the same time. As it is shown in Figure 8, the left hand courtyard (Shattuck Hall) is bare, the middle one has vegetation and the right one has a water pool at its centre. 

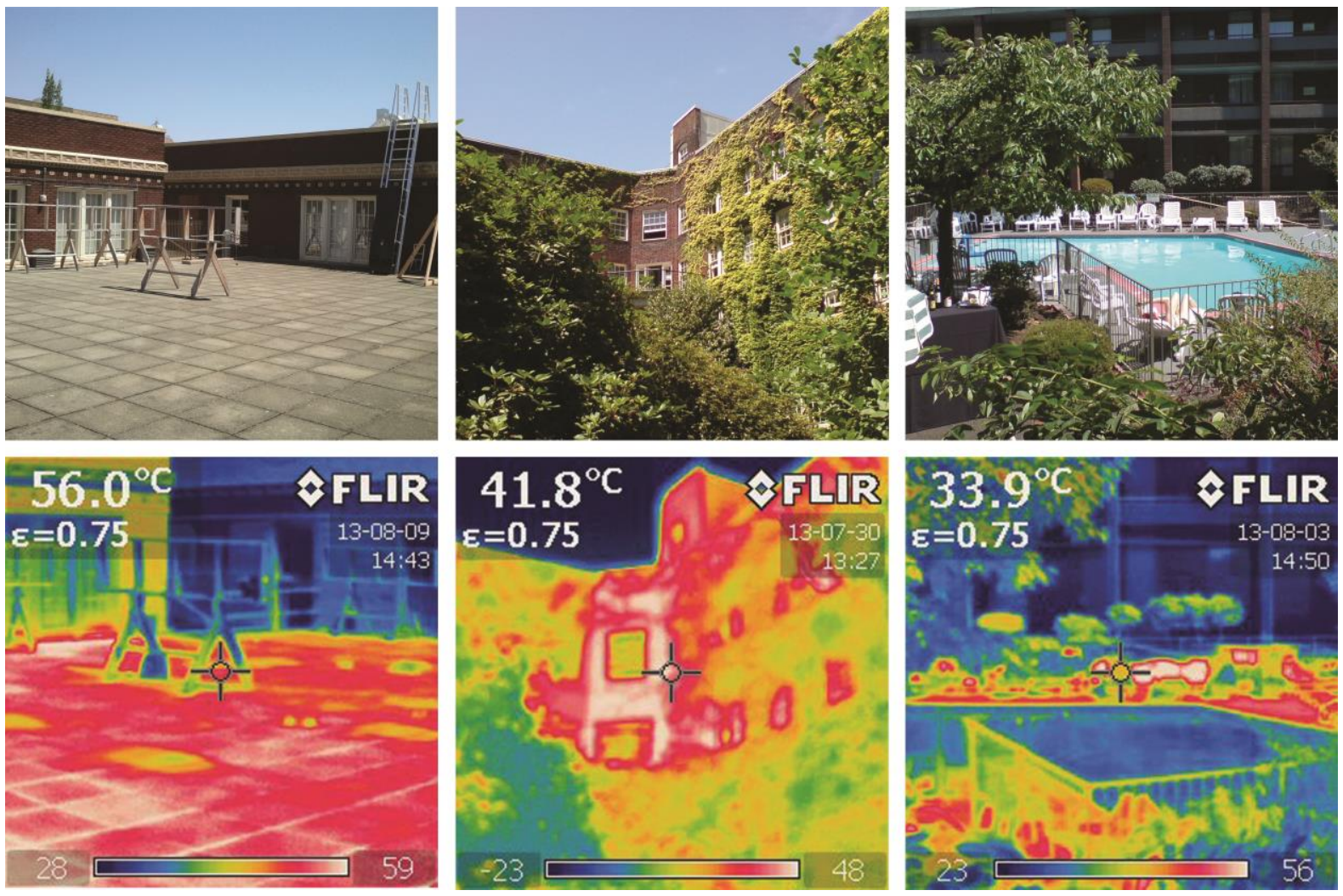

Figure 8: The three measured courtyards: bare, green and with water pool (points 3, 1 and 7, respectively in Figure 1-Phase 1).

The air temperature and relative humidity in these courtyards are plotted in Figure 9. As it is seen, the first courtyard in Shattuck Hall that is bare has the highest peak air temperature (maximum $33.3^{\circ} \mathrm{C}$ at $16: 30 \mathrm{PM}$ ). This courtyard has the lowest temperature and relative humidity during night among the other buildings, as well. The maximum diurnal temperature and relative humidity variation $(\Delta \mathrm{T}$ and $\Delta \mathrm{RH})$ were $18.1^{\circ} \mathrm{C}$ and $65.3 \%$, respectively. In contrast, the courtyard with vegetation has the smallest diurnal fluctuation $\left(\Delta \mathrm{T}=11.5^{\circ} \mathrm{C}\right.$ and $\Delta \mathrm{RH}=37.1 \%$ ) with a maximum temperature recorded of $28.7^{\circ} \mathrm{C}$ (at $18: 00 \mathrm{PM}$ ). The third courtyard with water pool had a thermal behaviour in between the previous two. Its peak temperature was very close to that in the bare courtyard (maximum $31.7^{\circ} \mathrm{C}$ ). In this case, the maximum diurnal temperature and relative humidity variation $(\Delta T$ and $\Delta R H)$ were $15.0^{\circ} \mathrm{C}$ and $50.0 \%$, respectively. To sum up, the maximum temperature differences between the green courtyard and the bare one was $4.7^{\circ} \mathrm{C}$ during the day. Moreover, vegetation made the second courtyard moderated (least fluctuated) in case of temperature and relative humidity variations. 

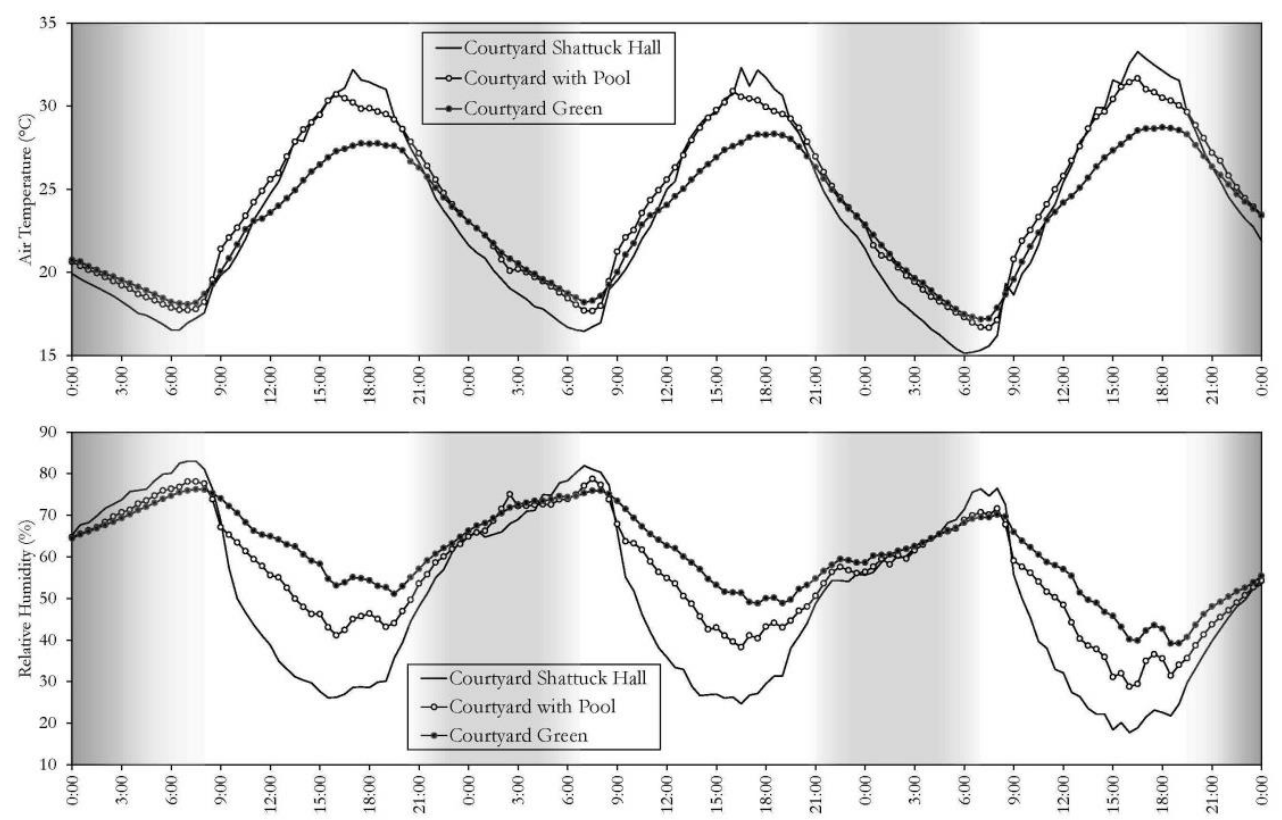

Figure 9: Air temperature and relative humidity in the measured courtyards.

The courtyards compared have different characteristics (such as their wall materials, pavements and dimensions). To investigate the effect of vegetation and water on the microclimate of a courtyard, the Shattuck Hall courtyard is simulated according to three scenarios (Figure 10). In the first one, the actual situation is simulated. In the second scenario, the ground of the courtyard is covered with grass. In the last scenario, a water pond is included in the bare courtyard. $T_{a}$ and $T_{m r t}$ at the centre of the courtyard on a summer day (July 20 $0^{\text {th }}$ ) are compared in Figure 11.

As it is seen, among the models the bare courtyard has the warmest air temperature and the water pond courtyard the coolest air temperature, mainly in the afternoon. The higher heat capacity of water could be a reason for this. The difference in mean radiant temperature is clearly visible during the daytime. $T_{\text {mrt }}$ rises drastically in all the three models around 6:00 AM due to irradiation by the sun. From 7:00 AM until 15:00 PM, the bare courtyard has the highest mean radiant temperature, and again the courtyard with water pond has the lowest. The maximum difference is $16^{\circ} \mathrm{C}$ at $13: 00 \mathrm{PM}$. This result is in accordance with several studies which have shown that $\mathrm{T}_{\text {mrt }}$ could be even $30^{\circ} \mathrm{C}$ different in two areas with only a difference of $0.5^{\circ} \mathrm{C}$ in air temperature $[54,55]$. In the evening, the bare courtyard that has a highly absorbing pavement (asphalt) is warmer than the other courtyards. 

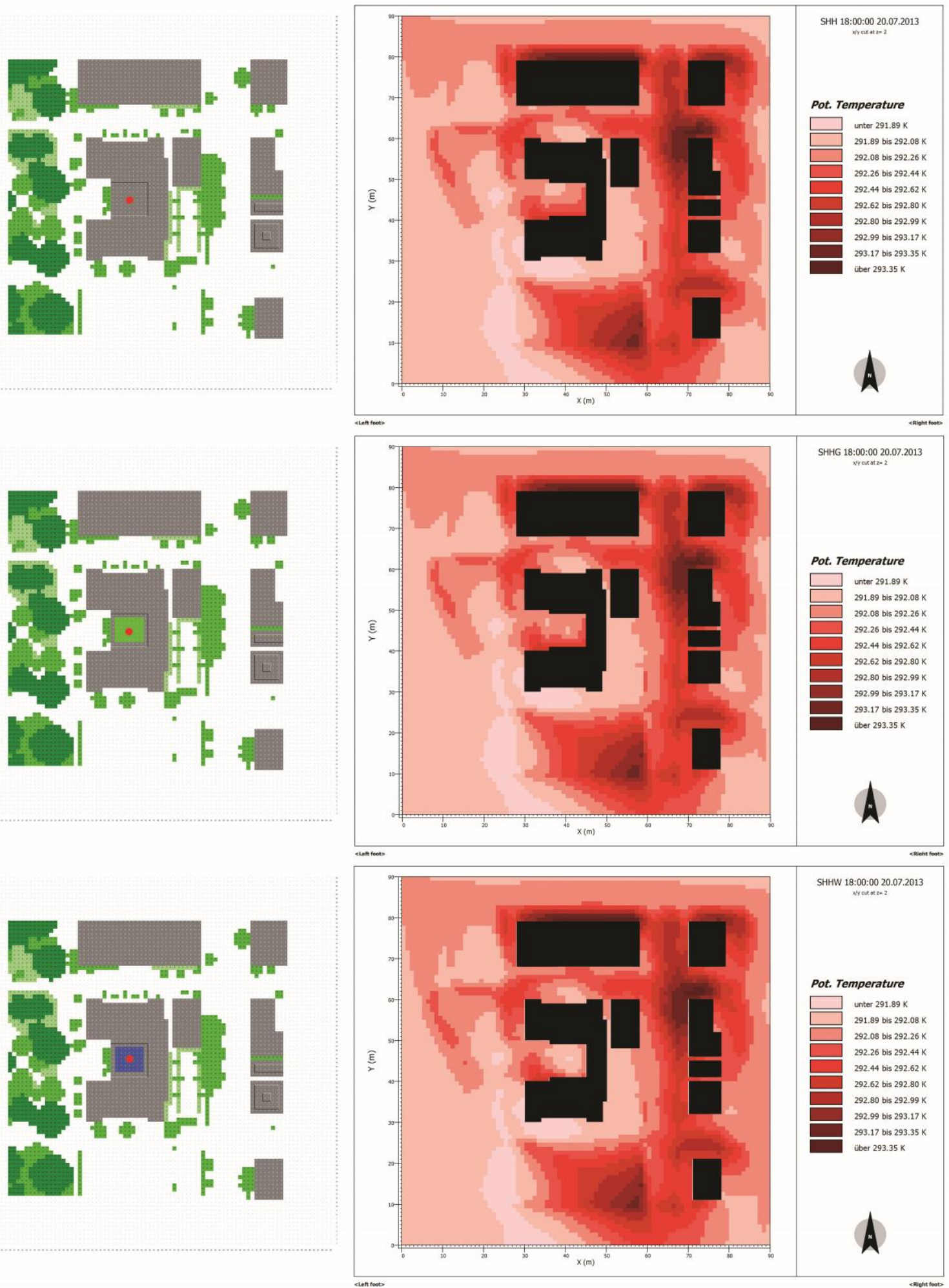

Figure 10: Air temperature in the three scenarios. Top: the bare courtyard, middle: the courtyard with grass, and bottom: the courtyard with water pond. 

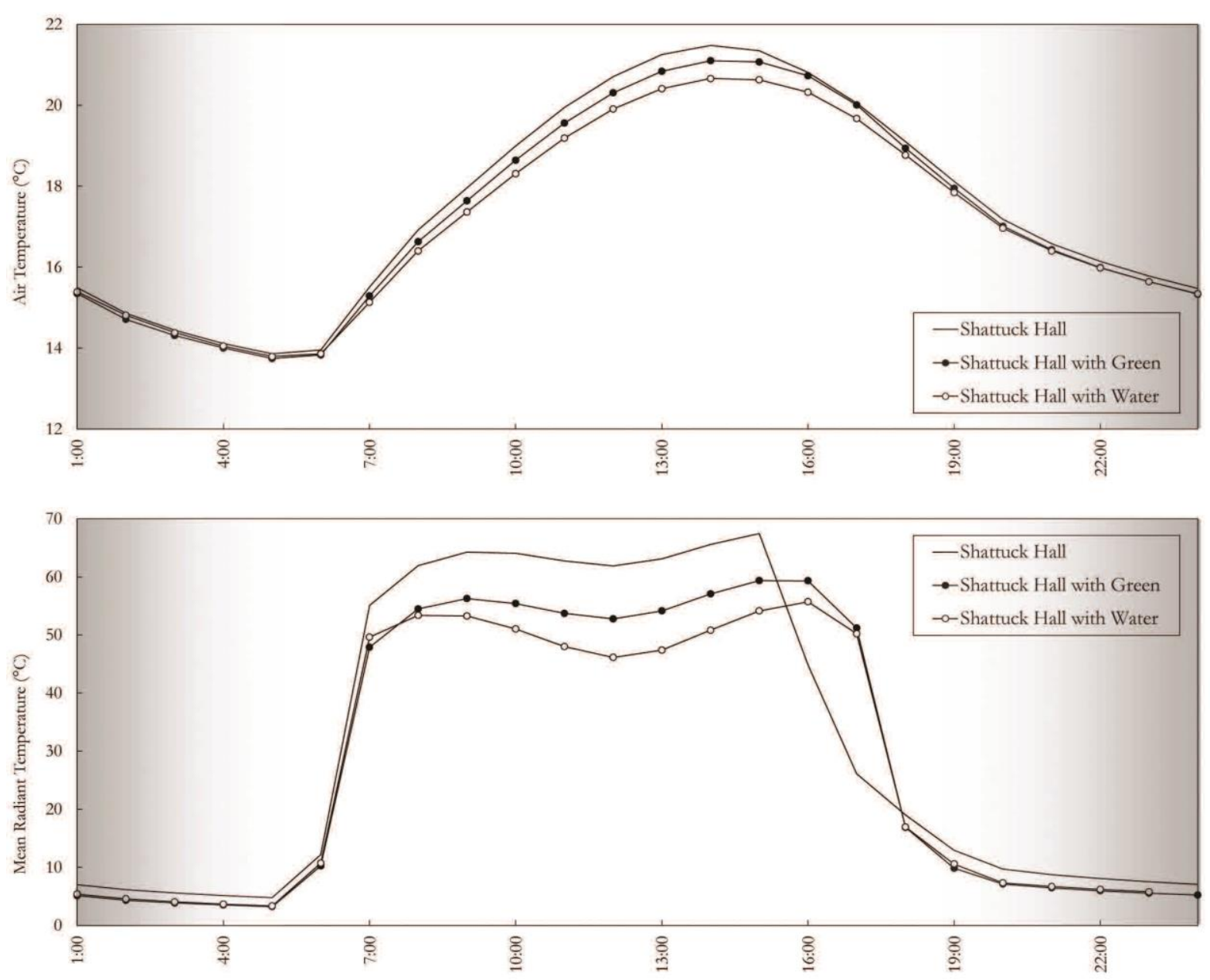

Figure 11: Air temperature (top) and mean radiant temperature (bottom) at the centre of the Shattuck hall courtyard according to the three scenarios: bare, green and with water pond.

\subsection{Scale 3: Shattuck Hall}

During the third phase, the effect of albedo was studied by changing the pavement surface on the Shattuck Hall courtyard. $5{ }^{*} 5 \mathrm{~m}^{2}$ of the existing pavement was covered with white and black cardboard (Figure 12). Infrared photography allowed observing the surface temperature differences at various moments (14:00 PM, 18:00 PM and 22:00 PM). Based on the spectrometer test, the albedos of the white and black cardboard were 0.91 and 0.37 , respectively. Comparing the two situations, the contrast between the white pavement and its surrounding is more visible than between the black pavement and its surrounding at 14:00 PM and 18:00 PM. The corner of the courtyard shown in the figure is the place where the Eastern (right) and Northern (left) facades meet each other. At 14:00 PM, the eastern façade 
(which had not received sun yet) is as cool as the white pavement; while the black pavement has a similar thermal behaviour to the northern façade (which had received sun from the early morning).
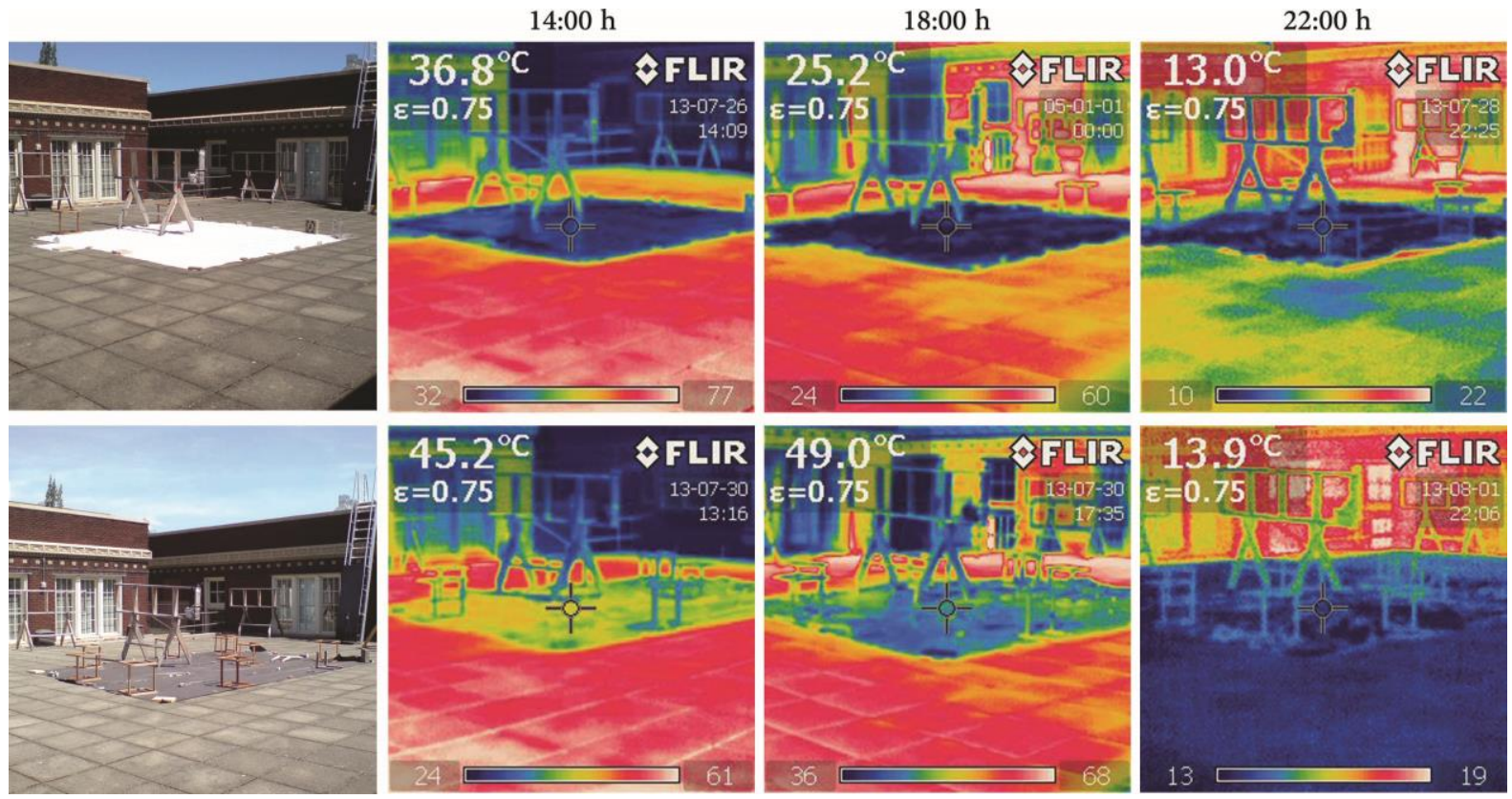

Figure 12: The effect of albedo change at different moments.

Figure 13 compares the new pavement (white and black) temperatures in accordance with the ambient air and the surrounding pavement temperatures. The white pavement temperatures are close to the ambient air temperatures. In contrast, the black pavement temperatures differ much from the ambient air temperatures. This is due to the higher albedo of the white pavement compared to the black one. The white pavement has absorbed less sun during the day, and its surface temperature is $38^{\circ} \mathrm{C}$ cooler than that of the surrounding surfaces at $14: 00 \mathrm{PM}$, and $23.5^{\circ} \mathrm{C}$ on average during the day. This daily average difference between the black pavement and its surroundings was $9.8^{\circ} \mathrm{C}$. 


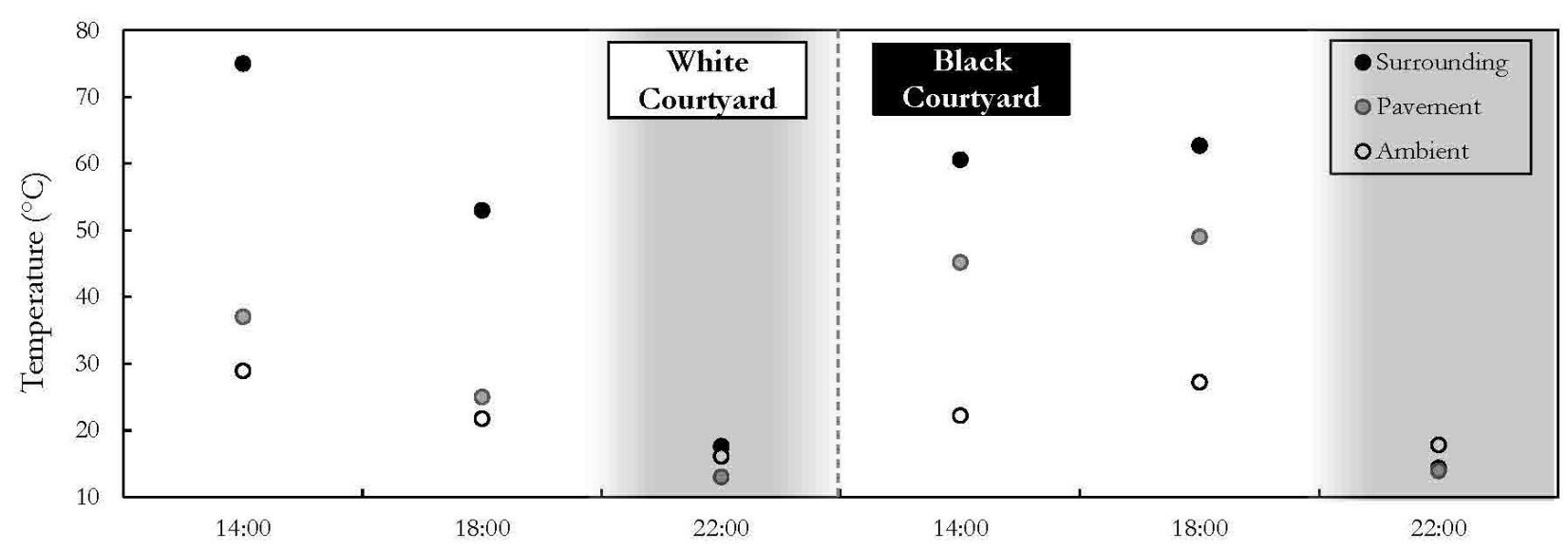

Figure 13: Temperature differences between surfaces of surrounding, white and black pavements and the ambient air.

Continuously measuring the black globe and air temperature at this building (1.5m height at the centre of the courtyard) made it possible to calculate the mean radiant temperature ( $\left.T_{\mathrm{mrt}}\right)$ to estimate the thermal comfort situation with white and black pavements. $T_{\text {mrt }}$ sums up all short and long wave radiation fluxes (direct and reflected) on a specific point. This parameter is calculated with the following equation:

$T_{m r}=\left[(G T+273)^{4}+\frac{1.1 \times 10^{8} \times v_{a}^{0.6}}{\varepsilon \times D^{0.4}}\left(G T-T_{a}\right)\right]^{0.25}-273$

Where

$\mathrm{T}_{\mathrm{mrt}}$ is the mean radiant temperature $\left({ }^{\circ} \mathrm{C}\right)$,

GT is the globe temperature $\left({ }^{\circ} \mathrm{C}\right)$,

$v_{a}$ is the air velocity near the globe $(\mathrm{m} / \mathrm{s})$,

$\varepsilon$ is the emissivity of the globe which normally is assumed 0.95 ,

$D$ is the diameter of the globe $(m)$ which typically is $0.15 \mathrm{~m}$, and

$\mathrm{T}_{\mathrm{a}}$ is the air temperature $\left({ }^{\circ} \mathrm{C}\right)$.

As it is shown in Figure 14, when using the white pavement, the globe temperature at the courtyard is much higher than when using the black pavement. This is due to the higher albedo of the white pavement. In this situation, the globe temperature receives more radiation when using the white pavement. Comparing these two, the average globe temperature in the courtyard is $2.9^{\circ} \mathrm{C}$ higher than in the east plaza when using the white cardboard and $2.0^{\circ} \mathrm{C}$ higher when using the black cardboard. This shows that using a bright pavement increases the globe temperature by almost $1^{\circ} \mathrm{C}$. 
Considering the air temperature on the two spots, the east plaza is warmer than the courtyard with white pavement with a maximum temperature difference of $1.9^{\circ} \mathrm{C}$. Contrary, the east plaza has only slightly higher air temperature than the courtyard with black pavement with a maximum difference of $0.6^{\circ} \mathrm{C}$. This shows how pavement with low albedo can increase the ambient air temperature in a microclimate.

Discussing mean radiant temperature $\left(T_{\mathrm{mrt}}\right)$ which is the most important factor to determine thermal comfort, Figure 12 shows how it differs when using white and black pavements. In general, the courtyard has a continuously higher $\mathrm{T}_{\text {mrt }}$ than the east plaza. In case of a white pavement, the differences are much higher than in case of a black pavement. Clearly, the average $T_{\text {mrt }}$ of the courtyard with white pavement is $12.4^{\circ} \mathrm{C}$ higher than the east plaza. This difference reduced to $2.9^{\circ} \mathrm{C}$ with the black pavement.

From thermal comfort point of view, having the lower mean radiant temperature with the black pavement leads to higher thermal comfort for a pedestrian because lower reflected sun is reflected from the ground. In contrast, the black pavement that reflects less sun and gets warmer than the white pavement. Therefore, this roof can conduct and radiate its heat to the indoor environment of the building, and consequently can increase the cooling demand of the building. This effect of outdoor heat mitigation on indoor energy demand could be useful for designers to consider the consequence of outdoor heat mitigation strategies. 

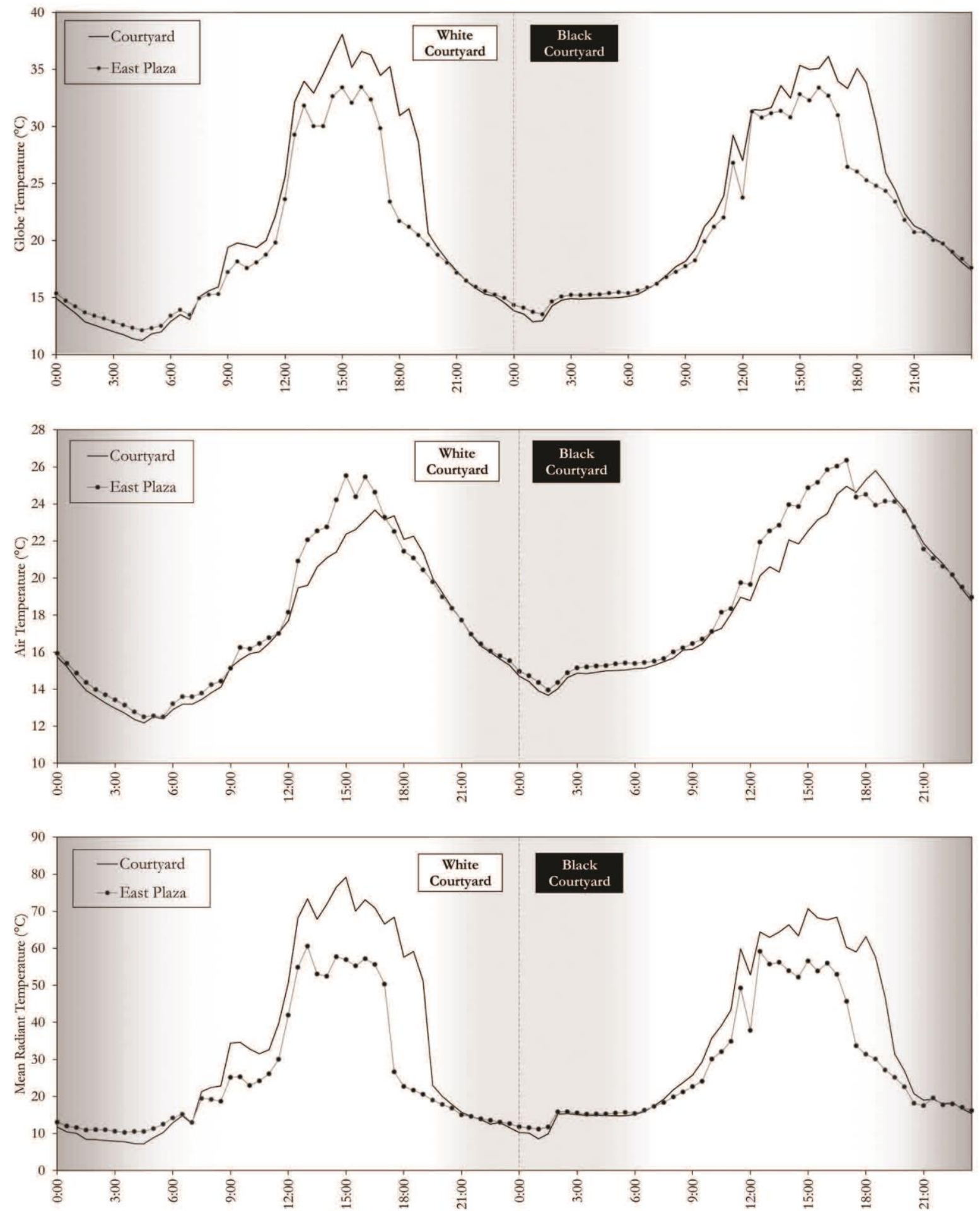

Figure 14: The globe, air and mean radiant temperature when using white and black pavements.

\section{Conclusion}


This research investigated different heat mitigation strategies through measurements and simulations in a university campus area in Portland, Oregon, USA. The study analysed local urban climate conditions in July and August of 2013 at three scales: the university campus, three courtyard buildings with different characteristics, and finally, one of the university buildings.

In the first phase, seven locations on the campus were measured. The maximum park cooling effect reported (i.e. temperature difference between a cool park and another location) was $5.8^{\circ} \mathrm{C}$ between the campus park and a parking lot with asphalt pavement (located $250 \mathrm{~m}$ apart). Moreover, the vegetation of the park as an obstruction, made the microclimate of the park more moderate (with less temperature fluctuations) as compared to the other measured locations. Furthermore, the campus was simulated for three different scenarios: the actual campus, a campus with water pools instead of a campus park, and the campus without any vegetation. It was found that the peak air temperature in the Shattuck Hall courtyard was $0.5^{\circ} \mathrm{C}$ and $1.6^{\circ} \mathrm{C}$ cooler in case of the park replaced by water bodies and in case of the existing park, respectively, compared to the bare campus. Since public transportation and asphalt pavements are inevitable in educational campuses, these findings could be useful for planners and designers to consider the cooling effect of vegetation and water within the public areas of university campuses. Moreover, there is a body of literature that confirms the environmental and psychological effects of natural elements in educational spaces.

In the second phase, three courtyard buildings on the campus with different characteristics were compared (one with vegetation, one with water bodies and a bare one- Shattuck Building courtyard). The air temperature in the bare courtyard was recorded as the highest and in the green courtyard as the lowest. The maximum temperature difference recorded was $4.7^{\circ} \mathrm{C}$ (at 16:30 PM). To have a clear understanding of the role of vegetation and water, simulations were performed for the bare courtyard. The courtyard was modelled in its current configuration and using test cases where the courtyard was first greened with vegetation or filled with a water body. The case with a water pond reduced the mean radiant temperature by $15.8^{\circ} \mathrm{C}$ compared to the bare situation.

In the last phase, the courtyard of the Shattuck Building was used to study the effect of albedo change. The existing pavement was partially covered with black and white cardboard with albedo of 0.37 and 0.91 , respectively. It was observed that the black treatment reduced the globe temperature and consequently mean radiant temperature, but increased the local air temperature. In contrast, the white treatment significantly increased the globe and mean 
radiant temperature $\left(0.9^{\circ} \mathrm{C}\right.$ and $2.9^{\circ} \mathrm{C}$ respectively) while producing a cooler local air temperature $\left(1.3^{\circ} \mathrm{C}\right)$. This phase showed how surface colours could affect indoor and outdoor thermal comfort in public and urban spaces.

This research suggests that in the temperate climate of Portland, vegetation and water bodies can reduce air temperature and significantly mean radiant temperature in canyons. This is in accordance with several studies that have shown the importance of using natural elements in urban areas. Finally, this paper mainly addressed air temperature and mean radiant temperature as key factors affecting outdoor thermal comfort; while, future studies can make this study more advanced with showing the role of moisture and other indices on outdoor thermal comfort in urban canyons. Considering the fact that most of metropolitan cities like Portland have university and educational campuses, planners and designers can use the benefit of greening these spaces as a strategy to mitigate urban heat island.

\section{Acknowledgment}

This research was partially supported by the Department of Energy under Award Number \#DE-EE0003870.

\section{References}

[1] T.R. Oke, Boundary Layer Climates, Routledge, New York, 1987.

[2] A.H. Rosenfeld, H. Akbari, S. Bretz, B.L. Fishman, D.M. Kurn, D. Sailor, H. Taha, Mitigation of urban heat islands: materials, utility programs, updates, Energy and Buildings, 22 (3) (1995) 255-265.

[3] C.S.B. Grimmond, M. Roth, T.R. Oke, Y.C. Au, M. Best, R. Betts, G. Carmichael, H. Cleugh, W. Dabberdt, R. Emmanuel, E. Freitas, K. Fortuniak, S. Hanna, P. Klein, L.S. Kalkstein, C.H. Liu, A. Nickson, D. Pearlmutter, D. Sailor, J. Voogt, Climate and More Sustainable Cities: Climate Information for Improved Planning and Management of Cities (Producers/Capabilities Perspective), Procedia Environmental Sciences, 1 (0) (2010) 247-274.

[4] J.A. Voogt, T.R. Oke, Thermal remote sensing of urban climates, Remote Sensing of Environment, 86 (3) (2003) 370-384.

[5] H. Taha, Meso-urban meteorological and photochemical modeling of heat island mitigation, Atmospheric Environment, 42 (38) (2008) 8795-8809.

[6] M. Santamouris, Cooling the cities - A review of reflective and green roof mitigation technologies to fight heat island and improve comfort in urban environments, Solar Energy, (0) (2013).

[7] L.Y. Xu, X.D. Xie, S. Li, Correlation analysis of the urban heat island effect and the spatial and temporal distribution of atmospheric particulates using TM images in Beijing, Environmental Pollution, 178 (0) (2013) 102-114.

[8] J. Kapsomenakis, D. Kolokotsa, T. Nikolaou, M. Santamouris, S.C. Zerefos, Forty years increase of the air ambient temperature in Greece: The impact on buildings, Energy Conversion and Management, 74 (0) (2013) 353-365.

[9] E. Carnielo, M. Zinzi, Optical and thermal characterisation of cool asphalts to mitigate urban temperatures and building cooling demand, Building and Environment, 60 (0) (2013) 56-65. 
[10] U. Mazzali, F. Peron, P. Romagnoni, R.M. Pulselli, S. Bastianoni, Experimental investigation on the energy performance of Living Walls in a temperate climate, Building and Environment, 64 (0) (2013) 57-66.

[11] B.C. Hedquist, A.J. Brazel, Seasonal variability of temperatures and outdoor human comfort in Phoenix, Arizona, U.S.A, Building and Environment, (0).

[12] A.M. Coutts, E. Daly, J. Beringer, N.J. Tapper, Assessing practical measures to reduce urban heat: Green and cool roofs, Building and Environment, 70 (0) (2013) 266-276.

[13] M. Taleghani, M. Tenpierik, A. van den Dobbelsteen, R. de Dear, Energy use impact of and thermal comfort in different urban block types in the Netherlands, Energy and Buildings, 67 (0) (2013) 166-175.

[14] M. Taleghani, M. Tenpierik, S. Kurvers, A. van den Dobbelsteen, A review into thermal comfort in buildings, Renewable and Sustainable Energy Reviews, 26 (0) (2013) 201-215.

[15] H. Akbari, S. Konopacki, Energy effects of heat-island reduction strategies in Toronto, Canada, Energy, 29 (2) (2004) 191-210.

[16] Y. Hirano, T. Fujita, Evaluation of the impact of the urban heat island on residential and commercial energy consumption in Tokyo, Energy, 37 (1) (2012) 371-383.

[17] H. Radhi, S. Sharples, Quantifying the domestic electricity consumption for air-conditioning due to urban heat islands in hot arid regions, Applied Energy, 112 (0) (2013) 371-380.

[18] M. Hart, D. Sailor, Quantifying the influence of land-use and surface characteristics on spatial variability in the urban heat island, Theor Appl Climatol, 95 (3-4) (2009) 397-406.

[19] T.R. Oke, Canyon geometry and the nocturnal urban heat island: Comparison of scale model and field observations, Journal of Climatology, 1 (3) (1981) 237-254.

[20] A. Dimoudi, A. Kantzioura, S. Zoras, C. Pallas, P. Kosmopoulos, Investigation of urban microclimate parameters in an urban center, Energy and Buildings, 64 (0) (2013) 1-9.

[21] H. Taha, Urban climates and heat islands: albedo, evapotranspiration, and anthropogenic heat, Energy and Buildings, 25 (2) (1997) 99-103.

[22] H. Akbari, H.D. Matthews, Global cooling updates: Reflective roofs and pavements, Energy and Buildings, 55 (0) (2012) 2-6.

[23] M. Taleghani, M. Tenpierik, A. van den Dobbelsteen, Energy performance and thermal comfort of courtyard/atrium dwellings in the Netherlands in the light of climate change, Renewable Energy, 63 (0) (2014) 486-497.

[24] D.J. Sailor, A review of methods for estimating anthropogenic heat and moisture emissions in the urban environment, International Journal of Climatology, 31 (2) (2011) 189-199.

[25] W.L. Chow, R. Pope, C. Martin, A. Brazel, Observing and modeling the nocturnal park cool island of an arid city: horizontal and vertical impacts, Theor Appl Climatol, 103 (1-2) (2011) 197-211.

[26] M. Srivanit, K. Hokao, Evaluating the cooling effects of greening for improving the outdoor thermal environment at an institutional campus in the summer, Building and Environment, 66 (0) (2013) 158-172.

[27] T.R. Oke, J.M. Crowther, K.G. McNaughton, J.L. Monteith, B. Gardiner, The Micrometeorology of the Urban Forest [and Discussion], Philosophical Transactions of the Royal Society of London. B, Biological Sciences, 324 (1223) (1989) 335-349.

[28] L. Howard, The climate of London, deduced from meteorological observations made in the metropolis and various places around it, Harvey and Darton, London, 1833.

[29] A. Dimoudi, M. Nikolopoulou, Vegetation in the urban environment: microclimatic analysis and benefits, Energy and Buildings, 35 (1) (2003) 69-76.

[30] L. Kleerekoper, M. van Esch, T.B. Salcedo, How to make a city climate-proof, addressing the urban heat island effect, Resources, Conservation and Recycling, 64 (0) (2012) 30-38.

[31] E.G. McPherson, A.R. Rowntree, J.A. Wagar, Energy-efficient landscapes, in: G. Bradley (Ed.) Urban Forest Landscapes- Integrating Multidisciplinary Perspectives, University of Washington Press, Seattle/London, 1994. 
[32] T.R. Oke, The energetic basis of the urban heat island, Quarterly Journal of the Royal Meteorological Society, 108 (455) (1982) 1-24.

[33] H. Taha, S. Douglas, J. Haney, Mesoscale meteorological and air quality impacts of increased urban albedo and vegetation, Energy and Buildings, 25 (2) (1997) 169-177.

[34] L. Pereira, A. Perrier, R. Allen, I. Alves, Evapotranspiration: Concepts and Future Trends, Journal of Irrigation and Drainage Engineering, 125 (2) (1999) 45-51.

[35] M. Nikolopoulou, N. Baker, K. Steemers, Thermal comfort in outdoor urban spaces:

understanding the human parameter, Solar Energy, 70 (3) (2001) 227-235.

[36] P. Höppe, Different aspects of assessing indoor and outdoor thermal comfort, Energy and Buildings, 34 (6) (2002) 661-665.

[37] D. Fiala, G. Havenith, P. Bröde, B. Kampmann, G. Jendritzky, UTCI-Fiala multi-node model of human heat transfer and temperature regulation, International Journal of Biometeorology, 56 (3) (2012) 429-441.

[38] S. Oliveira, H. Andrade, T. Vaz, The cooling effect of green spaces as a contribution to the mitigation of urban heat: A case study in Lisbon, Building and Environment, 46 (11) (2011) 21862194.

[39] F. Ali-Toudert, H. Mayer, Numerical study on the effects of aspect ratio and orientation of an urban street canyon on outdoor thermal comfort in hot and dry climate, Building and Environment, 41 (2) (2006) 94-108.

[40] F. Bourbia, F. Boucheriba, Impact of street design on urban microclimate for semi arid climate (Constantine), Renewable Energy, 35 (2) (2010) 343-347.

[41] T.-P. Lin, A. Matzarakis, R.-L. Hwang, Shading effect on long-term outdoor thermal comfort, Building and Environment, 45 (1) (2010) 213-221.

[42] H. Upmanis, I. Eliasson, S. Lindqvist, The influence of green areas on nocturnal temperatures in a high latitude city (Göteborg, Sweden), International Journal of Climatology, 18 (6) (1998) 681-700.

[43] J. Lindén, Nocturnal Cool Island in the Sahelian city of Ouagadougou, Burkina Faso, International Journal of Climatology, 31 (4) (2011) 605-620.

[44] R.A. Spronken-Smith, T.R. Oke, The thermal regime of urban parks in two cities with different summer climates, International Journal of Remote Sensing, 19 (11) (1998) 2085-2104.

[45] L.A. George, W. Becker, Investigating the urban heat island effect with a collaborative inquiry project, Geoscience Education, 51 (2) (2003) 237-243.

[46] M. Bruse, ENVI-met website, in, 2013.

[47] M. Bruse, H. Fleer, Simulating surface-plant-air interactions inside urban environments with a three dimensional numerical model, Environmental Modelling \& Software, 13 (3-4) (1998) 373-384. [48] S. Huttner, M. Bruse, P. Dostal, Using ENVI-met to simulate the impact of global warming on the microclimate in central European cities in: H. Mayer, A. Matzarakis (Eds.) 5th Japanese-German Meeting on Urban Climatology, Meteorologischen Instituts der Albert-Ludwigs-Universität Freiburg, 2008, pp. 307-312.

[49] M. Mahammadzadeh, Klimaschutz und Anpassung an die Klimafolgen: Strategien, Maßnahmen und Anwendungsbeispiele, IW-Medien, 2009.

[50] N.H. Wong, S. Kardinal Jusuf, A. Aung La Win, H. Kyaw Thu, T. Syatia Negara, W. Xuchao, Environmental study of the impact of greenery in an institutional campus in the tropics, Building and Environment, 42 (8) (2007) 2949-2970.

[51] D. Taleb, B. Abu-Hijleh, Urban heat islands: Potential effect of organic and structured urban configurations on temperature variations in Dubai, UAE, Renewable Energy, 50 (0) (2013) 747-762. [52] FAO, Global Ecological Zoning for the Global Forest Resources Assessment 2000, in, Forestry Department of the Food and Agriculture Organization, 2001.

[53] M. Kottek, J. Grieser, C. Beck, B. Rudolf, F. Rubel, World Map of the Köppen-Geiger climate classification updated, Meteorologische Zeitschrift, 15 (3) (2006).

[54] S. Berkovic, A. Yezioro, A. Bitan, Study of thermal comfort in courtyards in a hot arid climate, Solar Energy, 86 (5) (2012) 1173-1186. 
[55] J. Herrmann, A. Matzarakis, Mean radiant temperature in idealised urban canyons-examples from Freiburg, Germany, International Journal of Biometeorology, 56 (1) (2012) 199-203. 